\title{
Diversity and A Journal of Distributions Conservation Biogeography
}

\section{Determining the origin of invasions and demonstrating a lack of enemy release from microsporidian pathogens in the common wasps (Vespula vulgaris)}

\begin{tabular}{|r|l|}
\hline Journal: & Diversity and Distributions \\
\hline Manuscript ID: & DDI-2014-0036.R1 \\
\hline Manuscript Type: & Biodiversity Research \\
\hline Date Submitted by the Author: & n/a \\
\hline Complete List of Authors: & $\begin{array}{l}\text { Lester, Phil; Victoria University of Wellington, School of Biological } \\
\text { Sciences; } \\
\text { Gruber, Monica; Victoria University of Wellington, School of Biological } \\
\text { Sciences } \\
\text { Brenton-Rule, Evan; Victoria University of Wellington, School of Biological } \\
\text { Sciences } \\
\text { Archer, Michael; York St. John University, } \\
\text { Corley, Juan; INTA EEA Bariloche, Grupo de Ecología de Insectos } \\
\text { Dvorak, Libor; Mestske muzeum Marianske Lazne, } \\
\text { Masciocchi, Maite; INTA EEA Bariloche, Grupo de Ecología de Insectos } \\
\text { Van Oystaeyen, Annette; University of Leuven, Laboratory of Socio-Ecology } \\
\text { and Social Evolution }\end{array}$ \\
\hline Keywords: & $\begin{array}{l}\text { Biological invasions, enemy release, Nosema, pathogen, social wasp, } \\
\text { Vespula vulgaris }\end{array}$ \\
\hline \multicolumn{2}{|c}{} \\
\hline
\end{tabular}


1 Running header: Origin of \& enemy release in an invasive wasp

2

3 Determining the origin of invasions and demonstrating a lack of enemy release from

4 microsporidian pathogens in the common wasps (Vespula vulgaris)

5

6 P.J. Lester ${ }^{*}$, M.A.M. Gruber ${ }^{1}$, E. Brenton-Rule ${ }^{1}$, M. Archer $^{2}$, J.C. Corley ${ }^{3}$, L. Dvořák ${ }^{4}$, M.

7 Masciocchi $^{3}$ and A. Van Oystaeyen ${ }^{5}$

8

$9{ }^{1}$ Centre for Biodiversity and Restoration Ecology, Victoria University of Wellington, PO Box 10 600, Wellington, New Zealand,

112 York St. John University, Lord Mayor's Walk, York YO31 1EH, England,

$12{ }^{3}$ Grupo de Ecología de Insectos, INTA EEA Bariloche, Argentina,

$13{ }^{4}$ Mestske muzeum Marianske Lazne, Goethovo namesti 11, CZ-35301 Marianske Lazne,

14 Czech Republic,

$15{ }^{5}$ Laboratory of Socio-Ecology and Social Evolution, University of Leuven, Belgium

16

$17 *$ Correspondence:

18 Phil Lester, Centre for Biodiversity and Restoration Ecology, Victoria University of

19 Wellington, PO Box 600, Wellington, New Zealand, E-mail: phil.lester@vuw.ac.nz 


\section{ABSTRACT}

23 Aim Understanding the role of enemy release in biological invasions requires an assessment 24 of the invader's home range, the number of invasion events, and enemy prevalence. The 25 common wasp (Vespula vulgaris) is a widespread invader. We sought to determine the 26 Eurasian origin of this wasp and examined worldwide populations for microsporidian 27 pathogen infections to investigate enemy release.

\section{8 \\ Location Argentina, Eurasia, New Zealand}

$30 \quad C O I$ and $c y t b$ mitochondrial markers. A morphometric study using canonical discriminant 31 analysis was conducted on wing venation patterns. Microsporidian pathogens prevalence was 32 also examined using small subunit rRNA microsporidia-specific primers.

33 Results Our spatially structured haplotype network from the native range suggested a 34 longitudinal cline of wasp haplotypes along an east to west gradient. Six haplotypes were 35 detected from New Zealand, and two from Argentina. The populations from the introduced 36 range were genetically similar to the western European, UK and Ireland. The morphometric 37 analysis showed significant morphological variation between countries and supported the 38 Western European origin for New Zealand populations, though not for Argentine samples. 39 Microsporidian infection rates were highest in New Zealand samples (54\%), but no 40 significant differences in infection rates were observed between the invaded and native range. 41 Nosema species included matches to N. apis (a pathogen from honey bees) and N. bombi 42 (from bumble bees).

43 Main conclusions Multiple introductions of the common wasp have occurred in the invaded 44 range. A high microsporidian infection rate within the native range, combined with multiple 45 introductions and a reservoir of pathogens in other social insects such as bees, likely 
contributes to the high microsporidian infection rates in the invaded range. Enemy release is

likely to be more frequent when pathogens are rare in the home range, or are host-specific and rare in reservoir populations of the introduced range.

Keywords

Biological invasion, enemy release, Nosema, pathogen, social wasp, Vespula vulgaris

\section{INTRODUCTION}

54

The enemy release hypothesis proposes that invasive species can become abundant because of the absence of co-evolved natural enemies such as pathogens and parasites (Keane \& Crawley 2002; Torchin et al. 2003). Reduced enemy abundances are, however, likely to occur only probability of any invasive propagules being infected. The host specificity of natural enemies likewise must influence the prevalence and effects of natural enemies on invaders. Should existing exotic or native natural reservoirs of natural enemies occur in a new environment, they may spillback to arriving invasive species (Flory \& Keith, 2013). The potential role of alternative hosts for pathogens in maintaining, or in some situations reducing, the presence and abundance of pathogens in an environment has been clearly demonstrated with Lyme disease (Ostfeld \& Keesing, 2000).

The substantial influence that natural enemies such as pathogens can have on populations of social insects is exemplified in the global decline of bee populations. Colony 
71 collapse disorder is associated with widespread loss of honey bees. The exact causes of this

72 disorder are currently unknown, but likely involve a combination of several pathogens or

73 parasites and perhaps other factors such as pesticide exposure (Bromenshenk et al., 2010;

74 Evans \& Schwarz, 2011). Bumble bees are also experiencing a substantial population decline

75 associated with pathogens and low genetic diversity (Cameron et al., 2011). Pathogens

76 thought to be responsible for bumble bee and honey bee declines include microsporidians in

77 the genus Nosema. These studies suggest that pathogens can have a major effect on social

78 insects, which may be compounded by factors such as low genetic diversity. Invasive social

79 insects typically have low mean population genetic diversity as a result of a limited number of

80 invasive propagules (e.g. Corin et al., 2007; Gruber et al., 2012).

81 The common wasp (Vespula vulgaris) is an invasive species of major biodiversity and

82 conservation importance. Their high densities in the invaded range of countries such as New

83 Zealand and Argentina are the driver of their substantial ecological impacts. In New Zealand,

84 for example, densities of up to 370 wasps $\mathrm{m}^{-2}$ of tree trunk (Moller et al., 1991) and 34 nests

$85 \mathrm{ha}^{-1}$ (Beggs et al., 1998) have been observed. Under such conditions the probability of an orb-

86 web spider surviving to the end of a wasp season has been estimated at virtually zero (Toft \&

87 Rees, 1998). Common wasps also compete with native birds and have been recorded

88 attacking and killing chicks (Moller, 1990). These wasps are native to and widespread in

89 Eurasia (Archer, 1989; Dvořák, 2007). Within this native range, population densities appear

90 to fluctuate dramatically. Exceptional years of high abundance in the native range are

91 frequently followed by years of scarcity, with queen productivity varying by a factor of 100

92 between nests and years (Archer, 1981). These results indicate some form of endogenous

93 density-dependence and additional exogenous factors such as climate may promote variation

94 in abundance (Archer, 1981; Archer, 1985). Alternatively, fluctuations in wasp abundance

95 may be driven by pathogens and parasites. Such natural enemies are prevalent in Vespula spp. 
wasp populations within their native range (Rose et al., 1999; Evison et al., 2012), though

97

98

their abundance and influence in the introduced range is unknown.

A critical first step towards identifying co-evolved pathogens and assessing whether enemy release has occurred is to identify the home range. In the absence of the knowledge of a specific home range, the degree of enemy release may be overestimated (Colautti et al., 2005). The matching of an invasive species to their specific origin can be essential for the successful selection of a haplotype or genotype for biological control (Goolsby et al., 2006). Molecular methods have been particularly useful for determining the home range of invasive plants and animals, indicating invasion pathways and origins for a range of species (e.g. Goolsby et al., 2006; Corin et al., 2007). Morphological variation may also be useful for identifying intraspecific genetic variation and areas of origin (Nielsen et al., 1999; Abramoff et al., 2004; Al-Ghamdi et al., 2013). Our first aim in this study was to estimate the specific area within the Eurasian host range from which the New Zealand and Argentinian populations of the common wasp originated, using variation in mitochondrial DNA and morphology within the home range. We examined wasps from throughout the invaded range in New Zealand and Argentina to search for evidence of multiple successful introductions. Our second aim was to assess whether enemy release occurs in common wasp populations outside the home range by comparing the prevalence of Nosema microsporidian pathogens in the invaded and native range. Microsporidian pathogens may be important for in bee colony collapse disorder (Bromenshenk et al., 2010; Evans \& Schwarz, 2011). Moreover, these pathogens have also been demonstrated to infect and multiply in Vespula wasps, with the potential to kill entire wasp nests (Fantham \& Porter, 1913). 
119 METHODS

120

121 Samples

122 Wasps were obtained by contacting entomologists located throughout the native and invaded

123 range. Samples of foraging workers or workers from nests were either freshly collected for

124 this study, or were from preserved samples (Fig. 1; Supplementary material Table S1). If

125 wasps were collected from nests, only a single individual from the nest was subsequently used

126 in the analysis. We note that while we achieved collection of samples from a representative

127 distribution of these wasps, given their wide distribution it is likely that we have missed

128 genetic diversity occurring in under-sampled regions such as Asia and Russia. Common

129 wasps were only recently detected in Argentina (Masciocchi et al., 2010) and the samples

130 from this country spanned their entire known distribution at the time of collection (February

131 and March 2013). Australia has been invaded by the common wasp (Richards, 1978), but

132 despite attempts to collect fresh samples no Australian specimens were obtained and only two

133 historic samples from the 1970s were sourced. DNA extractions from these specimens were

134 not successful. Australian entomologists we contacted suggested that common wasp

135 populations had been superseded by the more recently arrived German wasp (V. germanica).

136 For the phylogenetic analysis, we used an individual German wasp ( $V$. germanica) as an

137 outgroup, which was collected in Auckland, New Zealand. Note that the range of the common

138 wasp was previously thought to extend into North America, although recent work has

139 demonstrated ' $V$. vulgaris' in this region are actually $V$. alascensis (Carpenter \& Glare, 2010).

140

141 Wasp phylogenetic relationships

142 To ascertain the phylogenetic relationships and prevalence of microsporidian infections

143 among the $V$. vulgaris samples from the native and introduced ranges, we sequenced DNA 
144 from wasp workers sampled throughout these ranges (Fig. 1). Wasps were dissected and the

145 gut used for both wasp DNA and microsporidian extractions (these are primarily gut

146 parasites). We extracted DNA using a standard digestion with $0.2 \%$ SDS and $0.5 \mathrm{mg} / \mathrm{ml}$

147 proteinase-k until the tissue dissolved (2-4 h), followed by phenol/chloroform purification,

148 ethanol precipitation and re-suspension in Tris-EDTA buffer.

149 We used PCR to amplify portions of the mitochondrial loci COI (cytochrome oxidase

150 I) and $c y t b$ (cytochrome b) for phylogenetic analysis. The mitochondrial primers were $\mathrm{C} 1-\mathrm{J}-$

151 1718(Sid) 5'-GGA GGA TTT GGA AAT TGG CTT ATT CC-3' and C1-N-2191(Nancy) 5'-

152 CCC GGT AAA ATT AAA ATA TAA ACT TC-3' for COI, and CB1 5'- TAT GTA CTA

153 CCA TGA GGA CAA ATA TC-3' and CB2 5' - ATT ACA CCT CCT AAT TTA TTA GGA

154 AT-3' for $c y t b$ (Simon et al., 1994). Each $15 \mu$ PCR reaction consisted of $1 \mu$ l of template

155 DNA ( 20 ng DNA), 1 X PCR Buffer, $0.4 \mathrm{mg} / \mathrm{mL}$ of bovine serum albumin (BSA), $1.5 \mathrm{mM}$

$156 \mathrm{MgCl} 2,200 \mu \mathrm{M}$ of each dNTP, $0.4 \mu \mathrm{M}$ of each primer and 0.1 Unit of Taq DNA Polymerase

157 (Fisher). Thermal cycling conditions for COI and $c y t b$ consisted of initial denaturation at

$15894^{\circ} \mathrm{C}$ for $2 \mathrm{~min}$, followed by 40 cycles of denaturing at $94^{\circ} \mathrm{C}$ for $30 \mathrm{~s}$, annealing for $40 \mathrm{~s}$ at

$15945^{\circ} \mathrm{C}$, and extension at $72^{\circ} \mathrm{C}$ for $1 \mathrm{~min}$, followed by a final extension at $72^{\circ} \mathrm{C}$ for $10 \mathrm{~min}$.

160 Amplified products were purified using ExoSAP-IT (US Biochemicals, Cleveland, Ohio) and

161 sequenced directly with an ABI 3730XL Genetic Analyser (Applied Biosystems) by

162 Macrogen Inc., Seoul, Korea and the Massey Genome Service, Palmerston North, New

163 Zealand. Genomic DNA was sequenced from 103 samples. We manually checked for quality,

164 edited and aligned the DNA sequences using MEGA5.1 (Tamura et al., 2011). The sequence

165 of the sample from Mongolia was of poor quality and was discarded from further analysis.

166 We used BLASTn searches of the NCBI (GenBank) nucleotide (nr) database to confirm the

167 authenticity of our 105 clean sequences as $V$. vulgaris (and the outgroup $V$. germanica). For 
168 our phylogenetic analysis we assessed the $c y t b$ (420 bases) and COI datasets (432 bases)

169 separately, and both sets of sequences as a concatenated dataset (852 bases).

170 To determine the most appropriate model of sequence evolution for our datasets, we

171 used Bayesian Information Criterion (BIC) scores derived in MEGA, which also estimated

172 base frequencies, substitution rates, the proportion of invariable sites (I), and the uniformity of

173 substitution rates among sites $(\mathrm{G})$. The models of evolution selected as best-fitting differed

174 slightly for the three datasets, but the best-fitting model for the concatenated dataset also

175 ranked among the three best models for the cytb and COI datasets using BIC scores

176 (Supplementary material Table S2). In addition, the Hasegawa-Kishino-Yano model

177 (Hasegawa et al., 1985) with a gamma distribution parameter (HKY + G model) ranked

178 among the four best-fitting models for all three datasets using Akaike Information Criterion

179 (AICc) and Maximum Likelihood $(\ln L)$ values. We therefore considered the models of

180 evolution to be comparable and used the model selected for the concatenated dataset

$181(\mathrm{HKY}+\mathrm{G}=0.16)$ for tree-building. The estimated model and parameters were then used to

182 generate a Maximum Composite Likelihood (MCL) tree and the level of support was assessed

183 with 2000 bootstrap replicates in MEGA. We also used MEGA to calculate percentage

184 genetic distances and standard errors (S.E.) among groups of individuals. The HKY model is

185 not implemented in MEGA for genetic distance calculation, so we used the Tamura-Nei

186 model (TN93; Tamura \& Nei, 1993) with a gamma parameter of 0.16 as this was among the

187 best-fitting models for the concatenated dataset.

188 We visualised the relationships among mitochondrial haplotypes and regions by

189 creating a spatially structured haplotype network in TempNet (Prost \& Anderson, 2011). We

190 grouped samples into seven geographical regions: Asia (China, Mongolia); Eastern Europe

191 (Poland, Hungary, Austria, Czech Republic, Greece, Slovakia); Northern Europe (Russia, 
192 Estonia, Finland, Sweden); Western Europe (France, Belgium, Germany, Italy, Spain); UK \&

193 Ireland (England, Ireland, Northern Ireland).

194 To test the closest genetic relationships of samples from individual regions to our New

195 Zealand and Argentine samples, we used generalised linear models (GLM) with a negative

196 binomial distribution and log link function using the MASS package (Venables \& Ripley,

197 2002) in R version 2.15.1 (Ihaka \& Gentleman, 1996; R Development Core Team, 2012).

198 Genetic distance to the New Zealand or Argentinian samples was modelled as the response

199 variable and region as the predictor variable. To assess correlations between geographic and

200 genetic distance (i.e. isolation by distance) we conducted a Mantel test using the ade4

201 package (Dray \& Dufour, 2007) in R, using 9999 replicates.

202

203 Wasp wing morphology

204 In addition to genetic markers we examined variation in wing morphology as another

205 potential character that may be useful to derive the area of origin for the invasive populations.

206 Wing morphology has been utilized to successfully derive sub-species status in other

207 hymenopteran populations, such as honey bees (e.g. Ruttner et al., 1978). The right forewing

208 of adult worker wasps was removed and placed on a microscope slide, with an additional slide

209 placed on top to flatten the wing. A digital photograph was taken of the wing and the

210 distances between 25 wing nodes were measured using ImageJ (Abramoff et al., 2004; Al-

211 Ghamdi et al., 2013). To account for variation in wasp size, data were standardized by

212 dividing the distance between two nodes by the distance between the nodes b and i (Fig. 2a).

213 We only analysed samples from countries from which we had $\geq 10$ individual wasps.

214 To examine variation in wing morphology between wasp populations in the native and

215 invaded range of $V$. vulgaris, we used canonical discriminant analysis in the candisc package

216 (Friendly \& Fox, 2013) in R. We first utilized stepwise discriminant function analysis to 
217 reduce the number of variables in an attempt to avoid issues associated with co-linearity.

218 Country was used as the discriminator variable and "unexplained variance" used as the

219 stepwise method. The F-value to enter variables was set at $\alpha<0.05$, and minimum

220 significance to remove variables at $\alpha>0.10$. The candisc output includes a Type II

221 MANOVA, which tested the hypothesis that there is morphological differentiation amongst

222 the populations.

223

224 Microsporidian pathogen prevalence

225 Small sub-unit rRNA (SSU rRNA) general microsporidia-specific primers, which amplify the

226 V1-V3 regions of the 16S (SSU) gene were used for the Nosema assay. The primers were V1f

227 5'-CAC CAG GTT GAT TCT GCC TGA C-3' and 530r 5'-CCG CGG CTG CTG GCA C-3'

228 (Baker et al., 1995) used the same DNA extractions as for the phylogenetic analysis, together

229 with additional extractions, and analysed all samples for microsporidian infection. Thermal

230 cycling conditions included initial denaturation at $94^{\circ} \mathrm{C}$ for $2 \mathrm{~min}$, followed by 35 cycles of

231 denaturing at $95^{\circ} \mathrm{C}$ for $40 \mathrm{~s}$, annealing at $60^{\circ} \mathrm{C}$ for $40 \mathrm{~s}$, and extension at $72^{\circ} \mathrm{C}$ for $40 \mathrm{~s}$,

232 followed by a final extension at $72^{\circ} \mathrm{C}$ for $10 \mathrm{~min}$. Triplicates of the microsporidian pathogen

233 assays were run to estimate false negative rates using the equation $1-\left(a /\left(b^{*} 3\right)\right)$, where $a$ was

234 the total number of positive amplifications and $b$ was the number of samples that resulted in at

235 least one positive amplification. Amplified products of microsporidian-positive PCR products

236 were purified and sequenced as for the wasp samples $(n=51)$. Although the resulting

237 sequences (186 bases) were of sufficient resolution to enable identification to genus level (and

238 species in some cases), low electropherogram peaks prevented a robust examination of

239 phylogenetic similarity or sequence diversity. We used BLASTn searches of the NCBI

240 (GenBank) nucleotide (nr) database to identify the closest matching species to our sequences. 
241 Estimates of mean microsporidian pathogen infection rates $( \pm 95 \%$ confidence

242 intervals) were calculated using 10,000 bootstraps in IBM SPSS v 20.0 (IBM Corp, 2011).

243 Infection rates were considered significantly different if confidence intervals did not overlap.

244

245 RESULTS

246

\section{Wasp phylogenetic relationships}

248 Our phylogenetic analysis revealed 33 unique $V$. vulgaris haplotypes among our samples (Fig.

249 3). The New Zealand samples were closest in genetic distance to those from Argentina, the

250 United Kingdom, France and Belgium (Fig. 1, Table S4). Six haplotypes were detected

251 among the New Zealand samples (Fig. 4), which grouped closely with Argentine haplotypes

252 (Fig. 3 and Fig. 4). Our spatially structured haplotype network suggested a longitudinal cline

253 of haplotype diversity in the native range, with the eastern European populations more similar

254 to the Asian populations, and UK \& Ireland populations more similar to western European

255 populations. The populations from the invaded range were more similar to the western

256 European, UK and Ireland haplotypes (Fig. 4 \& Fig. S1A).

257 The genetic distance between the New Zealand samples and all other regions except

258 Argentina was significantly greater than within New Zealand samples (Fig. S1, Table S3).

259 The genetic distance between the Argentine samples and other regions, compared to the

260 genetic distance between the Argentine samples followed a similar pattern to that of New

261 Zealand. Again, differences were not significant between Argentina and New Zealand (Fig.

262 S1, Table S3). The results of these tests were consistent with the spatial structure observed in

263 haplotype diversity and genetic distance, with the closest relationships between the native

264 range and New Zealand and Argentinian samples being those from the UK and Ireland. Our

265 Mantel test found a significant correlation between genetic and geographical distance in the 
266 native range (Fig. S4, $r=0.838, \mathrm{p}<0.001$ ) consistent with a longitudinal cline in genetic

267 variation.

268

269 Wasp wing morphology

270 We analysed for morphological differences between the wasp populations from different

271 countries or regions. Using these standardized measurements, the canonical discriminant

272 analysis indicated significant population differentiation (MANOVA F $\mathrm{F}_{9,117}=3.827, \mathrm{P}<0.001$ ).

273 The stepwise function of the analysis used 13 of the 25 possible measurements (Fig. 2b:

274 relative distances between a-b, c-d, d-e, e-f, j-k, k-1, n-o, q-r, b-p, e-q, h-r). New Zealand

275 samples grouped near the UK, Ireland, Belgium and France (Fig. 2b). Argentinian samples

276 were the most differentiated based on the canonical axis 1 , which explained $43.6 \%$ of the

277 morphological variation. The measurement giving the highest proportionate differentiation

278 between the New Zealand and Argentinian samples was e-q (Fig. 2a), which indicated this

279 measurement was on average 9.3\% smaller in Argentine samples relative to New Zealand

280 specimens.

281

282 Microsporidian pathogen prevalence

283 Our microsporidian pathogen assays revealed that the closest matching sequences on

284 GenBank were typically Nosema spp. with percentage cover of 97 - 100\% and identity of 97 -

$285100 \%$ in the majority of cases $(n=57 / 67)$. Some sample sequences $(n=6)$ were less well-

286 resolved (70-97\% cover and 79-92\% identity), and four sequences were unresolved. Specific

287 Nosema species matches on GenBank were to N. apis (two samples from Belgium and two

288 samples from Slovakia with 100\% cover and 100\% identity), and N. bombi (four samples

289 from New Zealand with 100\% cover and 98\% identity). Nucleotide signals in the 
290 electropherograms for a number of sample sequences were weak. Given these weak signals

291 we were not confident in undertaking any further analysis of microsporidian diversity.

The false negative rate among all samples was $56.86 \%$, which may account for the

293 higher microsporidian infection observed here relative to studies such as Evison et al. (2012).

294 The prevalence of microsporidian pathogen infection among regions ranged from $0 \%$ (Asia, $\mathrm{n}$

$295=2)$ to $54 \%($ New Zealand, $n=39$; Table 1), however, the variation in infection rates among

296 regions was not significant given that the $95 \%$ confidence intervals for the infection rates of

297 all regions overlapped (Table 1).

298

299

\section{DISCUSSION}

300

301

Understanding the role of enemy release in biological invasions requires an accurate

302

assessment of the invader's home range, the number of invasion events, and pathogen

303 infection rates. Our first aim in this study was to estimate the specific area within the Eurasian

304 host range from which the New Zealand and Argentinian populations originated. The two

305 mitochondrial DNA genes produced a distinct cline in the geographic structuring in the native

306 range of the common wasp. This cline was related to geographic distance, primarily along an

307 east to west gradient (Fig. 4). Clines may result from geographic variation in selection

308 pressure (e.g. Wunderle, 1981), from introgression following secondary contact (e.g. Cooke et

$309 a l ., 1985)$, or simply from isolation with increasing geographic distance or other

310 environmental variables (e.g. Brazeau et al., 2013). While a clear geographic cline was

311 observed, some haplotypes were shared in multiple geographic locations. For example,

312 haplotypes occurring in the UK and Ireland were present in Western and Eastern Europe. The

313 wasp collected from China was the only one to have a unique haplotype not shared with any

314 other region. The lack of distinct haplotype boundaries within the native range suggests that 
315 mixing or dispersal within these wasp populations might have occurred, which could have

316 been caused by either natural or human-aided means. Estimates of natural dispersal for

317 Vespid queen wasps range in the hundreds of meters per year, while human-aided transport of

318 overwintering or hibernating queens likely accounts for the their movement over tens of

319 kilometres per year (Donovan, 1991; Goodisman et al., 2001; Masciocchi \& Corley, 2012).

320 Human-aided transport of queens within the native range has likely resulted in the mixing of

321 haplotypes and could have contributed to the observed clinal pattern.

322 Six haplotypes were detected among the New Zealand samples and two haplotypes

323 were observed in the Argentinian samples. Given the geographic cline in the mitochondrial

324 DNA, these haplotypes indicate that the introduced populations in New Zealand and

325 Argentina both originated from Western Europe. In addition, the observation of several

326 haplotypes in Argentina and New Zealand indicates multiple successful incursions of the

327 common wasp into both countries. Common wasp nests are founded by a single queen

328 (Archer, 2012) and mitochondrial DNA is maternally inherited. Hence, the occurrence of

329 multiple haplotypes within a country indicates the introduction of multiple queens into that

330 country. Established nests with a queen and hundreds or thousands of workers are readily

331 apparent and are thus unlikely to have been moved. It is much more likely that fertilized

332 queens have been moved after they have sought refuge for overwintering shelter (Beggs et al.,

333 2011). Vespine queens have long been observed to hibernate or overwinter in human goods

334 and produce, including between books in a case, in beetle holes in wood, under corrugated

335 iron sheeting, clinging to curtains or sacking (Duncan, 1939; Thomas, 1960). Quarantine

336 records spanning several decades in New Zealand indicate multiple interceptions of Vespid

337 wasps from a variety countries within Europe (e.g. France, Germany, Switzerland) and also

338 from their introduced range (e.g. Australia) (Keall, 1981; Townsend, 1984; Richardson, 339 1979). 
340 Within New Zealand, isolated individual specimens of the common wasp were

341 observed since 1921 in several widely separated locations, supporting the theory of multiple

342 introductions (Donovan, 1983). These New Zealand incursions may have come directly from

343 Europe, or populations established during the 1950's in nearby Australia (Anonymous, 1962)

344 may have also contributed propagules. The haplotype discovery curve (supplementary Figure

345 S2) indicates there are more haplotypes in New Zealand than we observed, implying that

346 there have been additional introductions. We thus cannot exclude incursions from regions

347 such as Asia into New Zealand or Argentina, but our data is indicative that the predominant

348 haplotypes established have their ultimate origin from Western Europe. The pathway of these

349 populations into Argentina is less clear. Given the genetic similarity between New Zealand

350 and Argentina, our results cannot discount the possibility of the Argentine populations

351 arriving via New Zealand. Chile was the likely source of the German wasp (Vespula

352 germanica) in Argentina (Beggs et al., 2011; Masciocchi \& Corley, 2012) and the common

353 wasp may have arrived in Argentina via a similar route. Given the highly invasive nature of

354 these wasps, the global propagule pressure from populations is likely to increase in an

355 exponential fashion due to an increasing number of potential propagule sources.

356 Wing morphology has been used as a character for differentiating intraspecific

357 variation in related insects including honey bees (Al-Ghamdi et al., 2013), with strong support

358 from mitochondrial DNA (Nielsen et al., 1999). With our wasps, the morphometric analysis

359 showed significant morphological variation between countries and supported the Western

360 European origin for New Zealand populations, though not for Argentine samples. We

361 expected considerable overlap between the New Zealand population and that of Argentina

362 given the genetic similarity between the populations. Perhaps some environmental feature can

363 influence wasp wing morphology, as it can for damselfies (Taylor \& Merriam, 1995). The 
364 lack of overlap between these samples suggests that variation wing morphology may not be a

365 good character for determining the origin of common wasp propagules.

366 The enemy release hypothesis predicts that the abundance or diversity of pathogens,

367 parasites and predators of invasive species is reduced in the introduced range, relative to the

368 native range, largely due to population bottlenecks during the colonization process (Keane $\&$

369 Crawley, 2002; Torchin et al., 2003). In the present study, we assessed the prevalence of the

370 microsporidian pathogens within both the native and the introduced range of the common

371 wasp. Microsporidian pathogens such as Nosema spp. have been associated with colony

372 collapse in honey bees (Bromenshenk et al., 2010; Evans \& Schwarz, 2011), and the

373 synergistic effects of low genetic diversity and Nosema spp. infection are thought to cause

374 declines in bumble bee populations of North America (Cameron et al., 2011).

375 We observed no significant differences in the prevalence of microsporodian infections

376 between populations of the native and introduced ranges, and thus no evidence to support the

377 enemy release hypothesis. Wattier et al. (2007) similarly found no microsporidian parasite

378 loss after invasion by an exotic amphipod. They concluded that the amphipod invasion was

379 either massive or recurrent, enabling the microsporidian pathogen to follow its host. Multiple

380 introductions of the common wasp have clearly occurred in New Zealand and Argentina. The

381 multiple incursions have likely facilitated multiple microsporidian introductions, especially

382 given the high infection rate of these pathogens within the home range of the wasps.

383 Microsporidia may also be acquired in the new range as exemplified in our study with

384 apparent infection N. bombi in the New Zealand samples, which is a pathogen of bumble

385 bees. Recent work has demonstrated that the individual Nosema species are capable of

386 infecting multiple host species and genera (Graystock et al., 2013; Fürst et al., 2014). Thus,

387 pathogens already present in an invaded zone may contribute to the pathogen loading for a

388 new invader. Furthermore, the duration since arrival into an area may be positively correlated 
389 with increasing pathogen accumulation, because there has been more time to acquire and

390 accumulate infections. This phenomenon has been observed in plants (Flory \& Clay, 2013)

391 and may apply to microsporidian infections in common wasp populations as well.

392

Wasps share the same habitat and compete for the same resources as honey bees and

bumble bees (Moller \& Tilley, 1989), and they also raid honey bee hives (Clapperton et al.,

394 1989). Together, these behaviours could increase the exposure of wasps to bee pathogens

395 such as $N$. apis and N. bombi. Evidence of such microsporidian pathogen spillover has been

396 recently observed between honey and bumble bees (Fürst et al., 2014). The rate of

397 microsporidian infection in wasps of up to $53 \%$ that we observed are much higher than those

398 previously noted in wasps or bees (e.g. 7-9\% in honey and bumble bees; Fürst et al., 2014).

399 Our results are of concern to apiarists and growers reliant on bumble bee pollination, as the

400 high infection rate in wasps may result in pathogen spillback. The management of wasp

401 populations may be a requirement in order to manage disease in bees.

402 The common wasp may thus be subject to pathogen acquisition, but the pathogenicity

403 of these different microsporidian species remains unknown. Pathogens like Nosema apis do

404 infect and multiply in Vespula germanica (F.), with the potential to kill entire wasp nests

405 (Fantham \& Porter, 1913). Our work has similarly demonstrated that N. apis can infect and

406 multiply in common wasps (unpublished data). Evison et al. (2012) also observed

407 microsporidian infection in common wasps. However, the presence of "pathogens" may thus

408 not always be deleterious and perhaps can even be advantageous for their hosts. For example,

409 one microsporidian species is thought to have little effect on its primary invasive ladybeetle

410 host, but the pathogen has lethal effects on native ladybeetles (Vilcinskas et al., 2013). This

411 microsporidian thus appears to facilitate the invasion and spread of its host. Further, even if

412 enemy release does occur it may not correlate with increased demographic success, for

413 example if enemies do not limit species in the native range (Prior \& Hellmann, 2013). Our 
414 work with microsporidian infections in the common wasp does not support the enemy release

415 hypothesis; but neither can we reject the hypothesis. Perhaps other key pathogens that are

416 actually pathogenic, and are rarer in wasps than microsporidian infections, are absent from

417 their invaded range.

418

419 ACKNOWLEDGEMENTS

420 For submitting samples of wasps that were used in this study we thank A.V. Antropov, R.

421 Barbieri, J. Barnard, H. Berman, G. Broad, B. Brown, L. Castro, E.G. Chambers, S. Curran,

422 T. Harris, N.A. Khrustalyova, H. Kovac, N.T.P. Lien, R. O'Toole, A. Perrard, F.R. Schnitzler

423 and B. Thompson. We thank three anonymous referees for their helpful comments. Funding

424 was provided by a RSNZ Marsden Grant and a RSNZ Charles Fleming Senior Scientist

425 Award to PJL, a RSNZ BayerBoost Scholarship to EB-R, Consejo Nacional de

426 Investigaciones Científicas yTécnicas, PIP 2010, Grant No. 11220090100043 to JCC, and

427 Victoria University of Wellington.

428

429 REFERENCES

430 Abramoff, M.D., Magalhaes, P.J. \& Ram, S.J. (2004) Image Processing with ImageJ.

431 Biophotonics International, 11, 36-42.

432 Al-Ghamdi, A.A., Nuru, A., Khanbash, M.S. \& Smith, D.R. (2013) Geographical distribution

433 and population variation of Apis mellifera jemenitica Ruttner. Journal of Apicultural

$434 \quad$ Research, 52, 124-133.

435 Anonymous (1962) Common English fruit wasp, Vespula vulgaris. Report of the Biological

436 Branch of the Department of Agriculture, Victoria, Australia, 2, 44. 
437 Archer, M.E. (1981) Successful and unsuccessful development of colonies of Vespula $438 \quad$ vulgaris (Linn.) (Hymenoptera: Vespidae). Ecological Entomology, 6, 1-10.

439 Archer, M.E. (1985) Population dynamics of the social wasps Vespula vulgaris and Vespula $440 \quad$ germanica in England. Journal of Animal Ecology, 54, 473-485.

441 Archer, M.E. (1989) A key to the world species of the Vespinae (Hymenoptera). Research 442 Monograph of the College of Ripon and St. John, 2, 1-41.

443 Archer, M.E. (2012) Vespine wasps of the world: behaviour, ecology \& taxonomy of the $444 \quad$ Vespinae. Siri Scientific Press, UK. 352 pp.

445 Baker, M.D., Vossbrinck, C.R., Didier, E.S., Maddox, J.V. \& Shadduck, J.A. (1995) Small 446 subunit ribosomal DNA phylogeny of various microsporidia with emphasis on AIDS 447 related forms. Journal of Eukaryotic Microbiology, 42, 564-570.

448 Beggs, J.R., Toft, R.J., Malham, J.P., Rees, J.S., Tilley, J.A.V., Moller, H. \& Alspach, P. 449 (1998) The difficulty of reducing introduced wasp (Vespula vulgaris) populations for $450 \quad$ conservation gains. New Zealand Journal of Ecology, 22, 55-63.

451 Beggs, J.R., Brockerhoff, E.G., Corley, J.C., Kenis, M., Masciocchi, M., Muller, F., Rome, Q. 452 \& Villemant, C. (2011) Ecological effects and management of invasive alien Vespidae. 453 Biocontrol, 56, 505-526.

454 Brazeau, D.A., Lesser, M.P. \& Slattery, M. 2013. Genetic structure in the coral, Montastraea 455 cavernosa: assessing genetic differentiation among and within Mesophotic reefs. PLoS $456 \quad O N E, \mathbf{8}, \mathrm{e} 65845$.

457 Bromenshenk, J.J., Henderson, C.B., Wick, C.H., Stanford, M.F., Zulich, A.W., Jabbour, 458 R.E., Deshpande, S.V., McCubbin, P.E., Seccomb, R.A., Welch, P.M., Williams, T., Firth, 459 D.R., Skowronski, E., Lehmann, M.M., Bilimoria, S.L., Gress, J., Wanner, K.W. \& 
460 Cramer, R.A. (2010) Iridovirus and microsporidian linked to honey bee colony decline.

$461 \quad P L o S O N E$, 5, e13181.

462 Cameron, S.A., Lozier, J.D., Strange, J.P., Koch, J.B., Cordes, N., Solter, L.F. \& Griswold, 463 T.L. (2011) Patterns of widespread decline in North American bumble bees. Proceedings 464 of the National Academy of Sciences of the United States of America, 108, 662-667.

465 Carpenter, T.M. \& Glare, T.J. (2010) Misidentification of Vespula alascensis as $V$. vulgaris in 466 North America (Hymenoptera: Vespidae; Vespinae). American Museum Novitates, 3690, $467 \quad 1-7$

468 Clapperton, B.K., Alspach, P.A., Moller, H. \& Matheson, A.G. (1989) The impact of 469 common and German wasps (Hymenoptera, Vespidae) on the New Zealand beekeeping $470 \quad$ industry. New Zealand Journal of Zoology, 16, 325-332.

471 Colautti, R.I., Muirhead, J.R., Biswas, R.N. \& MacIsaac, H.J. (2005) Realized vs apparent 472 reduction in enemies of the European starling. Biological Invasions, 7, 723-732.

473 Cooke, F., Findlay, C.S., Rockwell, R.F. \& Smith, J.A. (1985) Life history studies of the 474 lesser snow goose (Anser caerulescens caerulescens). III. The selective value of plumage 475 polymorphism: net fecundity. Evolution, 39, 165-177.

476 Corin, S.E., Lester, P.J., Abbott, K.L. \& Ritchie, P.A. (2007) Inferring historical introduction 477 pathways with mitochondrial DNA: the case of introduced Argentine ants (Linepithema 478 humile) into New Zealand. Diversity and Distributions, 13, 510-518.

479 Donovan, B.J. (1983) The common wasp is here. New Zealand Beekeeper, 180, 9-10.

480 Donovan, B.J. (1991) Spread of Vespula vulgaris (L.) assisted by vehicles. The Weta, 14, 2448126. 
482 Dray, S. \& Dufour, A.B. (2007) The ade4 package: implementing the duality diagram for 483 ecologists. Journal of Statistical Software, 22, 1-20.

484 Duncan, C.D. (1939) A contribution to the biology of North American Vespine wasps. 485 Standford University Press.

486 Dvořák, L. (2007) Social wasps (Hymenoptera: Vespidae) trapped with beer in European 487 forest ecosystems. Acta Musei Moraviae, Scientiae Biologicae, 92, 181-204.

488 Evans, J.D. \& Schwarz, R.S. (2011) Bees brought to their knees: microbes affecting honey 489 bee health. Trends in Microbiology, 19, 614-620.

490 Evison, S.E.F., Roberts, K.E., Laurenson, L., Pietravalle, S., Hui, J., Biesmeijer, J.C., Smith, 491 J.E., Budge, G. \& Hughes, W.O.H. (2012) Pervasiveness of parasites in pollinators. PLoS $492 \quad O N E, 7$, e30641.

493 Fantham, H.B. \& Porter, A. (1913) The pathogenicity of Nosema apis to insects other than 494 hive bees. Annals of Tropical Medicine and Parasitology, 8, 623-638.

495 Flory, S. \& Clay, K. (2013) Pathogen accumulation and long-term dynamics of plant 496 invasions. Journal of Ecology, 101, 607-613.

497 Friendly, M. \& Fox, J. (2013) Visualizing generalized canonical discriminant and canonical $498 \quad$ correlation analysis. Version 0.6-5.

499 Fürst, M.A., McMahon, D.P., Osborne, J.L., Paxton, R.J. \& Brown, M.J.F. (2014) Disease 500 associations between honeybees and bumblebees as a threat to wild pollinators. Nature, $501 \quad 506,364-366$.

502 Goodisman, M.A.D., Matthews, R.W. \& Crozier, R.H. (2001) Hierarchical genetic structure 503 of the introduced wasp Vespula germanica in Australia. Molecular Ecology, 10, 1423$504 \quad 1432$. 
505 Goolsby, J.A., De Barro, P.J., Makinson, J.R., Pemberton, R.W., Hartley, D.M. \& Frohlich,

506 D.R. (2006) Matching the origin of an invasive weed for selection of a herbivore haplotype

507 for a biological control programme. Molecular Ecology, 15, 287-297.

508 Graystock, P., Yates, K., Darvill, B., Goulson, D. \& Hughes, W.O.H. (2013) Emerging

509 dangers: deadly effects of an emergent parasite in a new pollinator host. Journal of

$510 \quad$ Invertebrate Pathology, 114, 114-119.

511 Gruber, M.A.M., Hoffmann, B.D., Ritchie, P.A. \& Lester, P.J. (2012) Genetic diversity is

512 positively associated with fine-scale momentary abundance of an invasive ant. Ecology

$513 \quad$ and Evolution, 2, 2091-2105.

514 Hasegawa, M., Kishino, H. \& Yano, T. (1985) Dating of human-ape splitting by a molecular

515 clock of mitochondrial DNA. Journal of Molecular Evolution, 22, 160-174.

516 Hufbauer, R.A. \& Sforza, R. (2008) Multiple introductions of two invasive Centaurea taxa

517 inferred from cpDNA haplotypes. Diversity and Distributions, 14, 252-261.

518 IBM Corp (2011) IBM SPSS Statistics for Windows, Version 20.0. Armonk, N.Y.

519 Ihaka, R. \& Gentleman, R. (1996) R: a language for data analysis and graphics. Journal of

$520 \quad$ Computational and Graphical Statistics, 5, 299-314.

521 Keall, J.B. (1981) Interceptions of insects, mites, and other animals entering New Zealand

522 1973-1978. Plant Health Diagnostic Station, Levin, New Zealand.

523 Keane, R.M. \& Crawley, M.J. (2002) Exotic plant invasions and the enemy release

524 hypothesis. Trends in Ecology and Evolution, 17, 164-170.

525 Masciocchi, M. \& Corley, J. (2012) Distribution, dispersal and spread of the invasive social 526 wasp (Vespula germanica) in Argentina. Austral Ecology, 38, 162-168. 
527 Masciocchi, M., Beggs, J.R., Carpenter, J.M. \& Corley, J.C. (2010) Primer registro de

528 Vespula vulgaris (Hymenoptera: Vespidae) en la Argentina. Revista de la Sociedad $529 \quad$ Entomológica Argentina, 69, 267-270.

530 Moller, H. (1990) Wasps kill nestling birds. Notornis 37, 76-77.

531 Moller, H. \& Tilley, J.A.V. (1989) Beech honeydew: seasonal variation and use by wasps,

532 honey bees, and other insects. New Zealand Journal of Zoology, 16, 289-302.

533 Moller, H., Tilley, J.A.V., Thomas, B.W. \& Gaze, P.D. (1991) Effect of introduced social

534 wasps on the standing crop of honeydew in New Zealand beech forests. New Zealand

$535 \quad$ Journal of Zoology, 18, 171-179.

536 Nei, M. \& Kumar, S. (2000) Molecular evolution and phylogenetics. Oxford University Press, $537 \quad$ New York.

538 Nielsen, D.I., Ebert, P.R., Hunt, G.J., Guzman-Novoa, E., Kinnee, S.A. \& Page, R.E. (1999)

539 Identification of africanized honey bees (Hymenoptera: Apidae) incorporating

540 morphometrics and an improved polymerase chain reaction mitotyping procedure. Annals

541 of the Entomological Society of America, 92, 167-174.

542 Ostfeld, R.S. \& Keesing, F. (2000) Biodiversity and disease risk: the case of Lyme disease.

$543 \quad$ Conservation Biology, 14, 722-728.

544 Prior, K.M. \& Hellmann, J.J. (2013) Does enemy loss cause release? A biogeographical

545 comparison of parasitoid effects on an introduced insect. Ecology, 94, 1015-1024.

546 Prost, S. \& Anderson, N.K. (2011) TempNet: An R-script for summarizing heterochronous

547 genetic data. Available from http://www.stanford.edu/group/hadlylab/tempnet/ 
548 R Development Core Team (2011) R: a language and environment for statistical computing.

549 R Foundation for Statistical Computing, Vienna, Austria. ISBN 3-900051-07-0,

$550 \quad$ http://www.R-project.org

551 Richards, O.W. (1978) Australian social wasps (Hymenoptera: Vespidae). Australian Journal 552 of Zoology, Supplement, 61, 1-132.

553 Richardson, C.A. (1979) Interceptions of insects, mites and other animals entering New

554 Zealand 1966-1972. Plant Health Diagnostic Station, Levin, New Zealand.

555 Rose E.A.F., Harris, R.J. \& Glare, T.R. (1999) Possible pathogens of social wasps

556 (Hymenoptera: Vespidae) and their potential as biological control agents. New Zealand

557 Journal of Zoology, 26, 179-190.

558 Ruttner, F., Tassencourt, L. \& Louveaux, J. (1978) Biometrical statistical analysis of the 559 geographic variability of Apis mellifera L. Apidologie, 9, 363-381.

560 Simon, C., Frati, F., Beckenbach, A., Crespi, B., Liu, H. \& Flook P. (1994) Evolution,

561 weighting and phylogenetic utility of mitochondrial gene sequences and a compilation of

562 conserved polymerase chain reaction "primers". Annals of the Entomological Society of

$563 \quad$ America, 87, 651-701.

564 Taylor, P.D. \& Marriam, G. (1995) Wing morphology of a forest damselfly is related to $565 \quad$ landscape structure. Oikos, 73, 43-48.

566 Tamura, K. \& Nei, M. (1993). Estimation of the number of nucleotide substitutions in the

567 control region of mitochondrial DNA in humans and chimpanzees. Molecular Biology and 568 Evolution, 10, 512-526.

569 Tamura, K., Peterson, D., Peterson, N., Stecher, G., Nei, M. \& Kumar, S. (2011) MEGA5:

570 Molecular Evolutionary Genetics Analysis using Maximum Likelihood, Evolutionary 
571 Distance, and Maximum Parsimony Methods. Molecular Biology and Evolution, 28, 2731$572 \quad 2739$.

573 Thomas, C.R. (1960) The European wasp (Vespula germanica Fab.) in New Zealand.

574 Information series, New Zealand Department of Scientific and Industrial Research, no. 27. $575 \quad 73 \mathrm{pp}$.

576 Toft, R.J. \& Rees, J.S. (1998) Reducing predation of orb-web spiders by controlling common 577 wasps (Vespula vulgaris) in a New Zealand beech forest. Ecological Entomology, 23, 9057895.

579 Torchin, M.E., Lafferty, K.D., Dobson, A.P., McKenzie, V.J., Kuris, A.M. (2003) Introduced $580 \quad$ species and their missing parasites. Nature, 421, 628-630.

581 Townsend, J.I. (1984) Interceptions of insects, mites and other animals entering New 582 Zealand, 1979-1982. Plant Health Diagnostic Service, Levin, New Zealand.

583 Venables, W.N. \& Ripley, B.D. (2002) Modern Applied Statistics with S. Fourth Edition. $584 \quad$ Springer, New York.

585 Vilcinskas, A., Stoecker, K., Schmidtberg, H., Rohrich, C.R. \& Vogel, H. (2013) Invasive 586 harlequin ladybird carries biological weapons against native competitors. Science, $\mathbf{3 4 0}$, $587 \quad 862-863$.

588 Wattier, R.A., Haine, E.R., Beguet, J., Martin, G., Bollache, L., Musko, I.B., Platvoet, D. \& 589 Rigaud, T. (2007) No genetic bottleneck or associated microparasite loss in invasive 590 populations of a freshwater amphipod. Oikos, 116, 1941-1953.

591 Wunderle, J.M. (1981) An analysis of a morph ratio cline in the bananaquit (Coereba 592 flaveola) on Grenada, West Indies. Evolution, 35, 333-344. 593 594 


\section{BIOSKETCH}

596 Phil Lester is a Professor in the School of Biological Sciences at Victoria University of

597 Wellington. He has been with Victoria and the Centre for Biodiversity \& Restoration Ecology

598 since 2001. His current focus with social wasp research is examining the diversity, abundance

599 and effects of pathogens in their native and introduced range.

600 Author contributions: P.J.L conceived the study; M.A.M.G and E.B-R collected data and

601 analysed the samples; P.J.L., E.B-R, M.A, J.C.C, L.D, M.M. and A.V.O contributed samples;

602 all authors helped write the manuscript and interpret the data.

603 


\begin{tabular}{|c|c|c|c|c|}
\hline \multicolumn{5}{|c|}{$\begin{array}{l}\text { Prevalence of microsporidian pathogen infection in the } \\
\text { p samples from the study regions. The } 95 \% \text { confidence } \\
\text { were obtained from a boot-strap analysis }\end{array}$} \\
\hline Region & $\mathbf{n}$ & positive & prevalence & 95\% CI range \\
\hline Argentina & 19 & 7 & 0.368 & $0.158-0.579$ \\
\hline Asia & 2 & 0 & 0.000 & $0.000-0.000$ \\
\hline Eastern Europe & 14 & 5 & 0.357 & $0.143-0.643$ \\
\hline New Zealand & 39 & 21 & 0.538 & $0.385-0.692$ \\
\hline Northern Europe & 7 & 1 & 0.143 & $0.000-0.429$ \\
\hline UK \& Ireland & 25 & 10 & 0.400 & $0.200-0.600$ \\
\hline Western Europe & 27 & 7 & 0.259 & $0.111-0.444$ \\
\hline
\end{tabular}

608

609 
610 Figure 1 Origins of the Vespula vulgaris samples. The samples are coloured according to their \% genetic similarity to one 611 or more of the specimens from New Zealand. The Chinese specimen showed the highest genetic difference $(2.9 \%$ base pairs 612 difference) compared to the New Zealand samples (Chinese sample location not shown on the map).
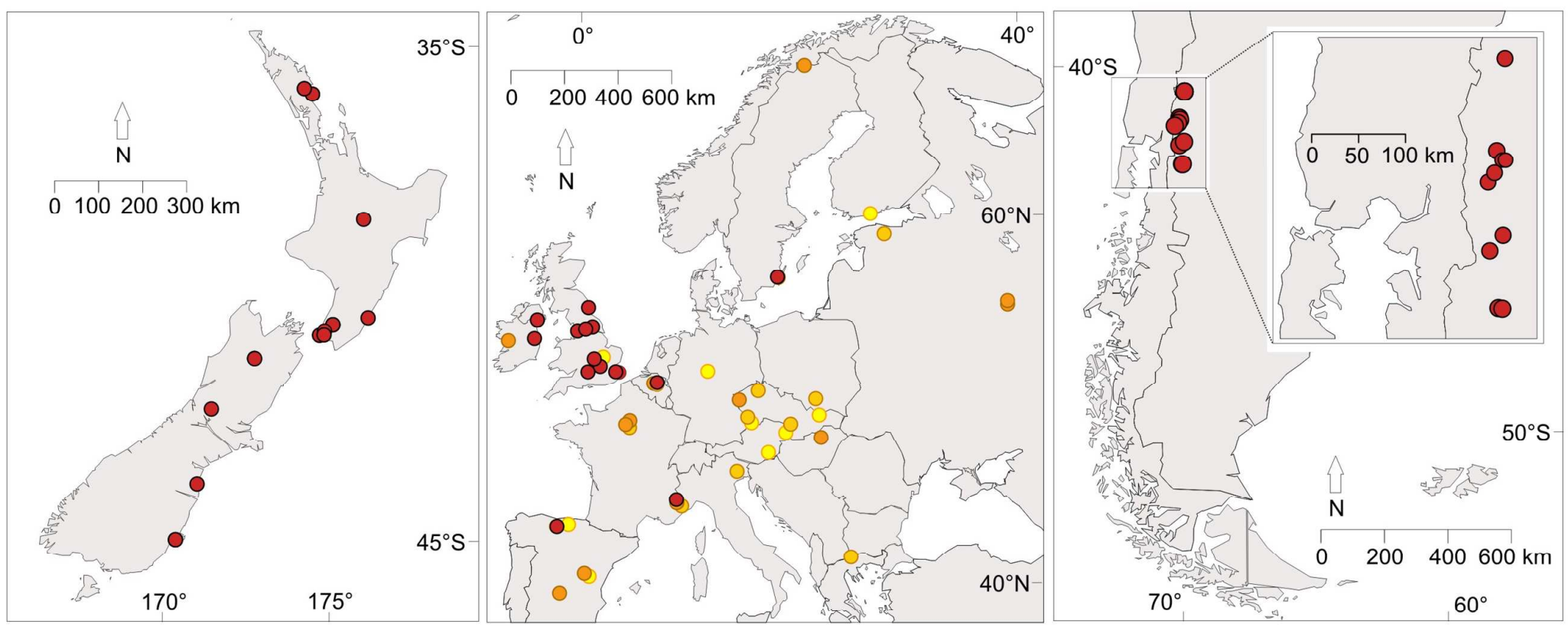

Minimum \% genetic distance to any of the New Zealand samples:

$0=0.00$

$=0.10$

$0=0.20$

$=0.40-2.90$ 
614 Figure 2 Canonical discriminant analysis examining variation in wasp wing 615 morphology within and between different countries. (i) Distances measured between 616 nodes on wing veins (ii) Dots represent centroids of the group, while circles are 95\% 617 confidence intervals. The alphabetical script (a-b, etc.) represents axes related to 618 individual distance measurements. We included wasps from countries from which we 619 had 10-22 wasp samples.
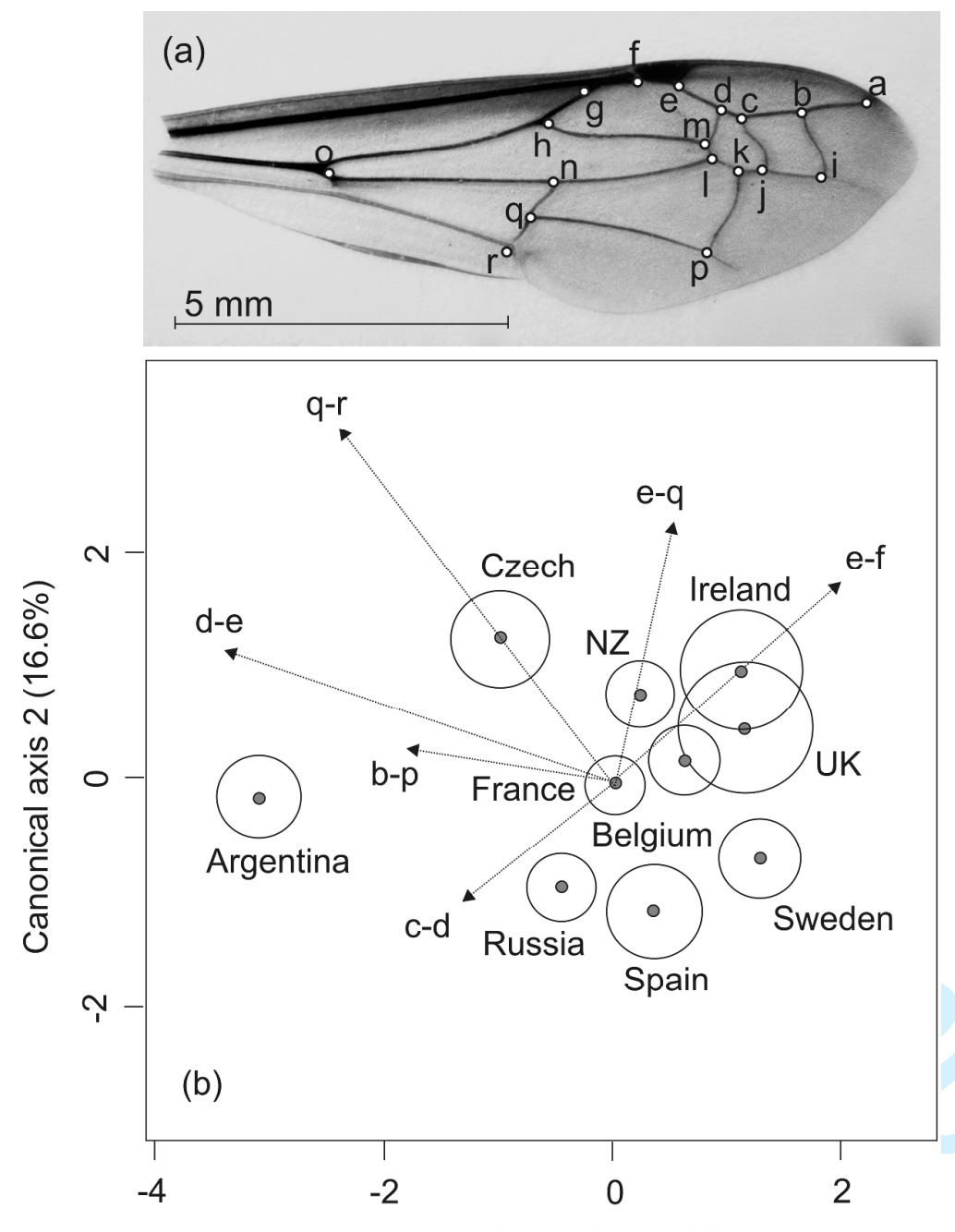

620

Canonical axis 1 (43.6\%)

621 
622 Figure 3 Maximum Composite Likelihood tree for Vespula vulgaris sampled

623 throughout the native and introduced range, with $V$. germanica used to root the

624 evolutionary tree. The tree was based on 2000 bootstraps of a Hasegawa-Kishino-

625 Yano $(\mathrm{HKY}+\mathrm{G})$ model with gamma parameter $(0.16)$, using a concatenated dataset of

$626 C O I$ and $c y t b$ mtDNA sequences. The estimates of levels of support shown are

627 bootstrap values greater than 50\%. Colours identify different regional groupings (see

628 Fig. 4). The dashed line connecting $V$. vulgaris is not to scale.

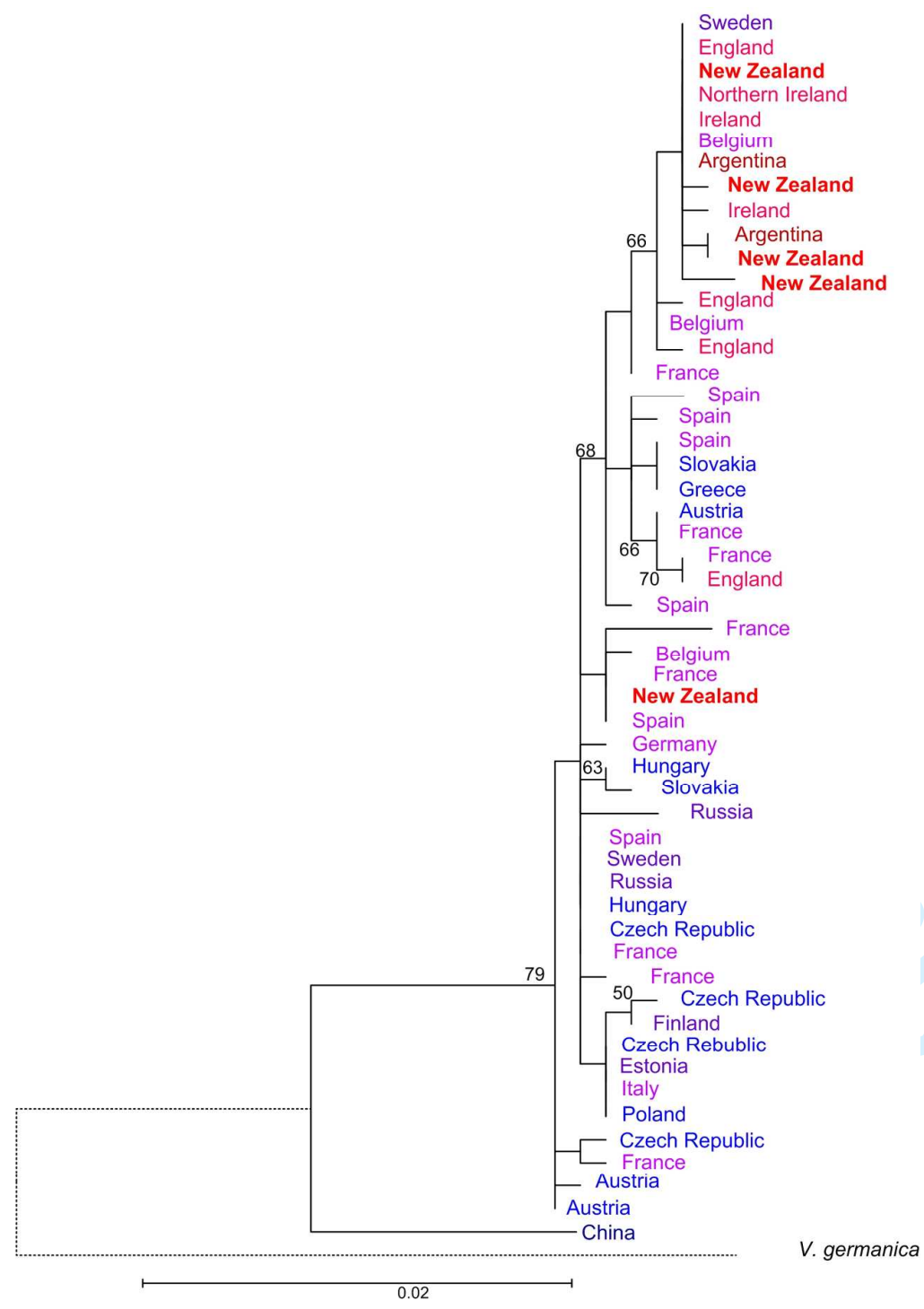


631 Figure $4 \quad$ Spatially structured haplotype network of Vespula vulgaris constructed 632 in TempNet. Lines between haplotype groups in adjacent layers indicate relationships 633 between the groups. Filled ellipses denote a positive sample and the relative number 634 of samples for each haplotype. Empty ellipses represent the absence of a haplotype in 635 a particular region. Each point along the lines between haplotypes indicates a base 636 substitution. Regional groupings are: Asia (China, $\mathrm{n}=1$ ); Eastern Europe (Poland, 637 Hungary, Austria, Czech Republic, Greece, Slovakia, n=16); Northern Europe 638 (Russia, Estonia, Finland, Sweden, n=9); Western Europe (France, Belgium, 639 Germany, Italy, Spain, n=26); UK \& Ireland (England, Ireland, Northern Ireland, $640 \mathrm{n}=17)$, New Zealand ( $\mathrm{n}=23)$, and Argentina $(\mathrm{n}=11)$.

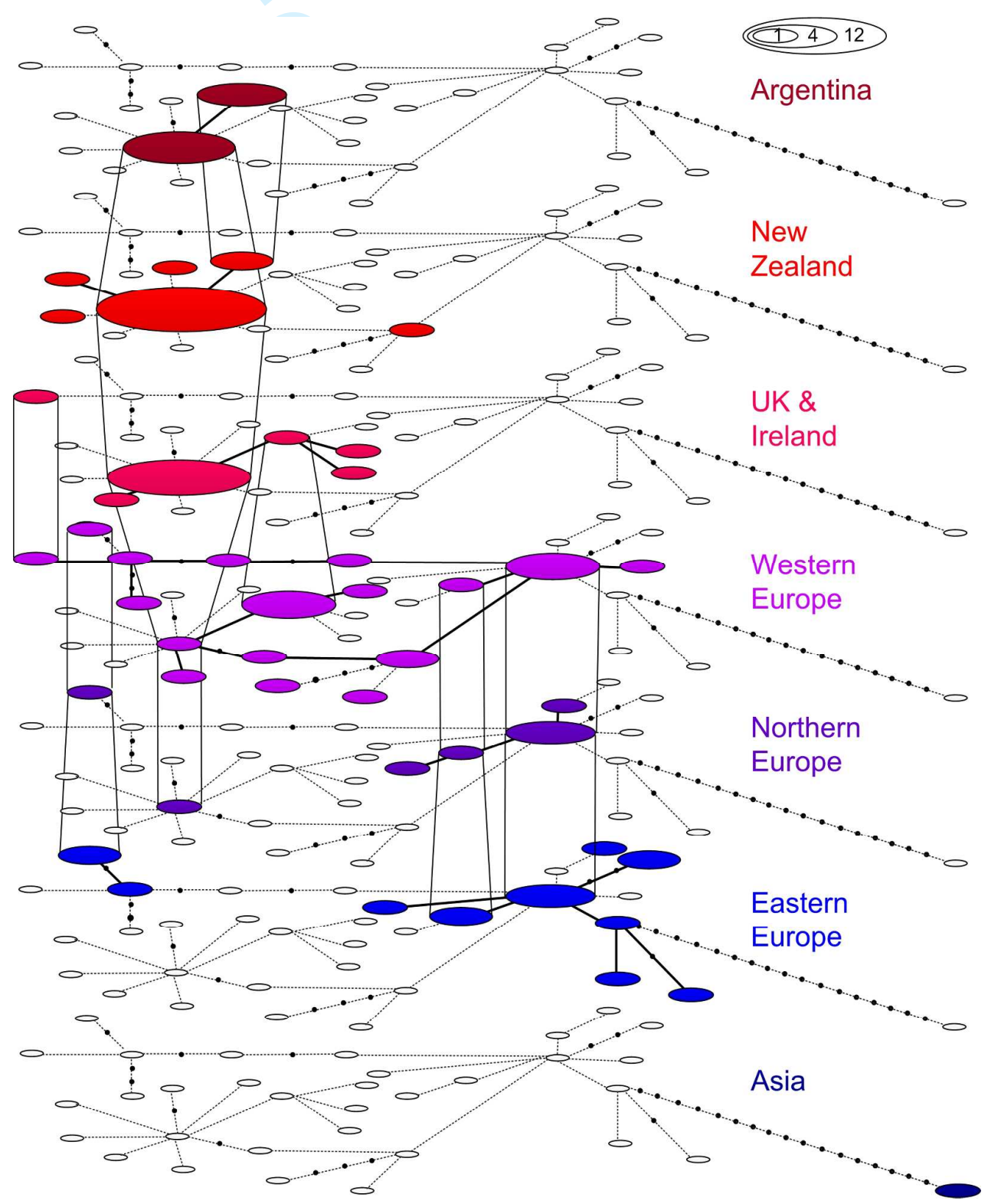


1 Running header: Origin \& enemy release in an invasive wasp

2

3 SUPPLEMENTARY MATERIAL

4

$5 \quad$ Running header: Origin of \& enemy release in an invasive wasp

6

7 No evidence of enemy release in the invaded range of the invasive common wasp

8 (Vespula vulgaris) from microsporidian pathogens

9

10 P.J. Lester ${ }^{1 *}$, M.A.M. Gruber ${ }^{1}$, E. Brenton-Rule ${ }^{1}$, M. Archer ${ }^{2}$, J.C. Corley ${ }^{3}$, L.

11 Dvořák $^{4}$, M. Masciocchi ${ }^{3}$ and A. Van Oystaeyen ${ }^{5}$

12

$13{ }^{1}$ Centre for Biodiversity and Restoration Ecology, Victoria University of Wellington,

14 PO Box 600, Wellington, New Zealand,

$15{ }^{2}$ York St. John University, Lord Mayor's Walk, York YO31 1EH, England,

$16{ }^{3}$ Grupo de Ecología de Insectos, INTA EEA Bariloche, Argentina,

$17{ }^{4}$ Mestske muzeum Marianske Lazne, Goethovo namesti 11, CZ-35301 Marianske

18 Lazne, Czech Republic,

$19{ }^{5}$ Laboratory of Socio-Ecology and Social Evolution, University of Leuven, Belgium

$22 *$ Correspondence author. E-mail: phil.lester@vuw.ac.nz 
26 Figure S1 Comparison of genetic distance between (and among) Vespula

27 vulgaris wasps from New Zealand (closed circles), Argentina (open circles) and other 28 regions sampled.

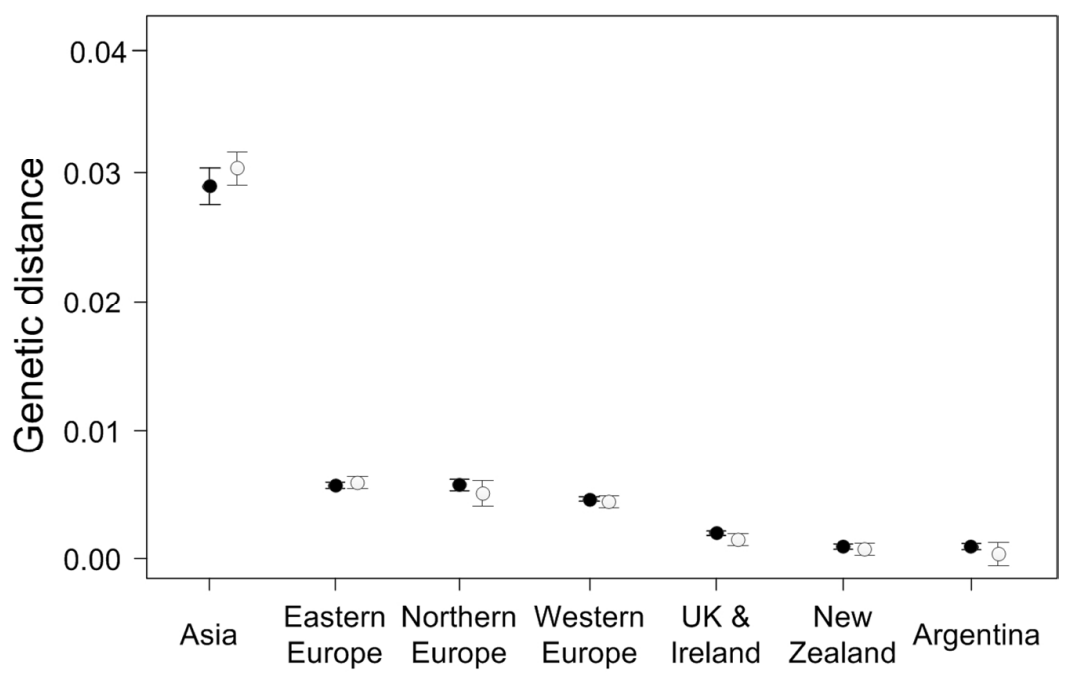

29

Region

30

31 Figure S2 Haplotype discovery curve for $V$. vulgaris sampled in New Zealand

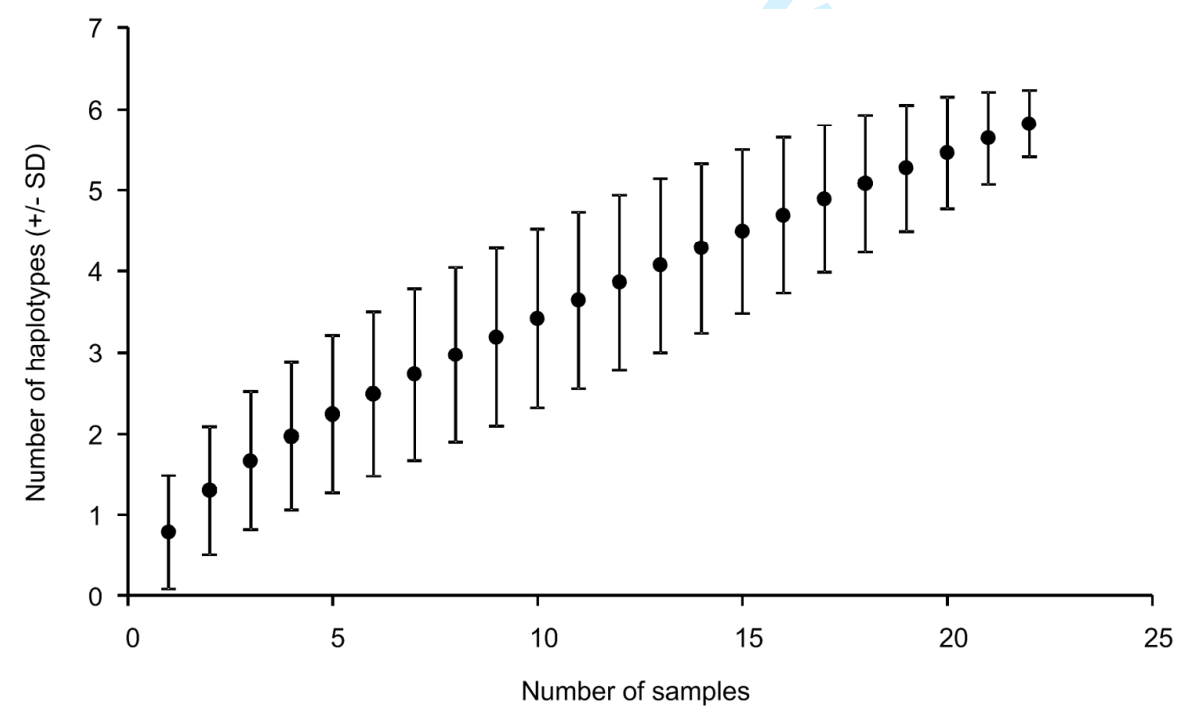


36 Figure S4 Relationship between genetic and geographical distance among all 37 samples from the native range. The black dashed line represents the line of best fit 38 (linear) and the solid orange line represents the line of best fit (smoothed using a loess 39 function in $\mathrm{R}$ with a span of 0.5 ). The relationship between genetic and geographic 40 distance was significant $(r=0.838, \mathrm{p}<0.001)$ and was also significant when the sample 41 from China (i.e. the most distant sample) was removed $(r=0.072, \mathrm{p}<0.001)$.

42

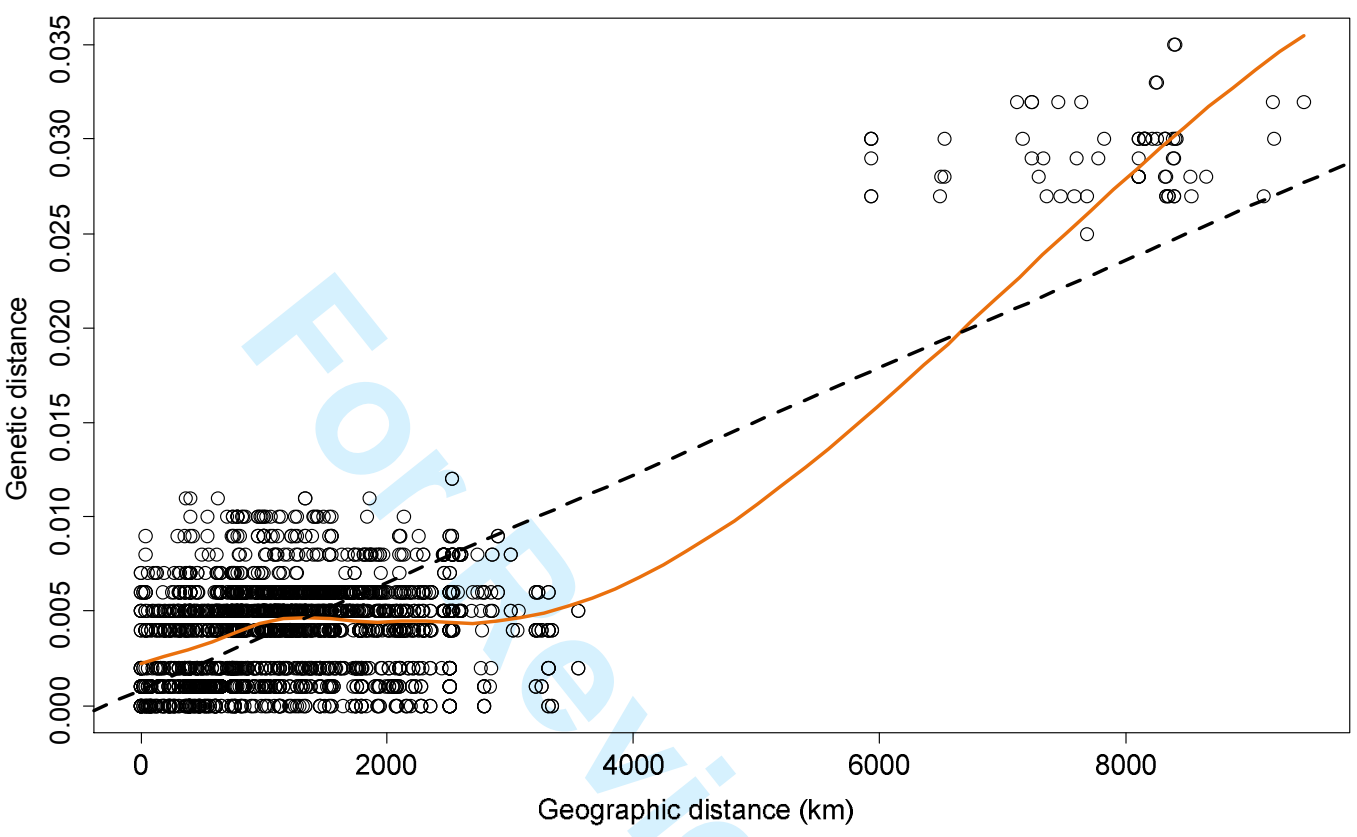


44 Table S1 Sampling origins and approximate collection date for Vespula vulgaris

45 and the single $V$. germanica used in this study. Wasps were typically collected

46 while foraging. When wasps were collected directly from nests, only one

$47 \quad$ individual per nest was used in the analysis

\begin{tabular}{|c|c|c|c|c|c|}
\hline Country & Locale & Latitude & Longitude & Collection date & Submitter \\
\hline Argentina & Chubut & -42.509 & -71.432 & 9 February 2013 & M. Masciocchi \\
\hline Argentina & Chubut & -42.507 & -71.425 & 9 February 2013 & M. Masciocchi \\
\hline Argentina & Chubut & -41.918 & -71.553 & 1 March 2012 & M. Masciocchi \\
\hline Argentina & Chubut & -41.918 & -71.553 & 1 March 2012 & M. Masciocchi \\
\hline Argentina & Río Negro & -41.850 & -71.417 & 18 February 2013 & M. Masciocchi \\
\hline Argentina & Río Negro & -41.348 & -71.617 & 6 February 2013 & M. Masciocchi \\
\hline Argentina & Río Negro & -41.271 & -71.508 & 6 February 2013 & M. Masciocchi \\
\hline Argentina & Río Negro & -41.161 & -71.411 & 5 February 2013 & M. Masciocchi \\
\hline Argentina & Río Negro & -41.119 & -71.402 & 17 February 2013 & M. Masciocchi \\
\hline Argentina & Río Negro & -41.099 & -71.447 & 5 February 2013 & M. Masciocchi \\
\hline Argentina & Neuquén & -40.161 & -71.358 & 15 March 2013 & M. Masciocchi \\
\hline Austria & Styria & 47.071 & 15.440 & 3 September 2012 & H. Kovac \\
\hline Austria & Mühlviertel & 48.585 & 14.035 & 13 July 2007 & L. Dvořák \\
\hline Austria & Mühlviertel & 48.708 & 13.854 & 13 July 2007 & L. Dvořák \\
\hline Belgium & Leuven & 50.797 & 4.985 & 12 September 2012 & A. Van Oystaeyen \\
\hline Belgium & Leuven & 50.797 & 4.985 & 12 September 2012 & A. Van Oystaeyen \\
\hline Belgium & Leuven & 50.842 & 4.671 & 18 September 2012 & A. Van Oystaeyen \\
\hline Belgium & Leuven & 50.885 & 4.659 & 25 July 2012 & A. Van Oystaeyen \\
\hline Belgium & Leuven & 50.885 & 4.659 & 25 July 2012 & A. Van Oystaeyen \\
\hline Belgium & Leuven & 50.885 & 4.659 & 25 July 2012 & A. Van Oystaeyen \\
\hline Belgium & Leuven & 50.926 & 4.985 & 21 September 2012 & A. Van Oystaeyen \\
\hline China & Shanxi & 35.302 & 111.671 & 1 July 2012 & N.T.P. Lien \\
\hline Czech Republic & Modrava & 49.023 & 13.495 & 12 August 2005 & L. Dvořák \\
\hline Czech Republic & Mariánské Lázně & 49.965 & 12.701 & 1 September 2012 & L. Dvořák \\
\hline Czech Republic & Mariánské Lázně & 49.965 & 12.701 & 1 September 2012 & L. Dvořák \\
\hline Czech Republic & Mariánské Lázně & 49.965 & 12.701 & 1 September 2012 & L. Dvořák \\
\hline Czech Republic & Chudolazy & 50.474 & 14.479 & 31 July 2004 & L. Dvořák \\
\hline Estonia & Järvamaa, Koeru & 58.965 & 26.026 & 19 July 2006 & L. Dvořák \\
\hline Finland & Helsinski-Herttoniemi & 60.197 & 25.017 & 6 September 2008 & L. Dvořák \\
\hline France & $\begin{array}{l}\text { Saint Martin-Vesubie } \\
\text { Saint-Dalmas-le }\end{array}$ & 44.117 & 7.287 & 1 July 2009 & A. Perrard \\
\hline France & $\begin{array}{l}\text { Selvage } \\
\text { Saint-Dalmas-le }\end{array}$ & 44.285 & 6.888 & 1 July 2009 & A. Perrard \\
\hline France & Selvage & 44.293 & 6.824 & 1 July 2009 & A. Perrard \\
\hline France & Meyronnes & 44.475 & 6.797 & 1 July 2011 & A. Perrard \\
\hline France & Marchais & 48.447 & 2.393 & 11 July 2007 & L. Dvořák \\
\hline France & Marchais & 48.447 & 2.393 & 11 July 2007 & L. Dvořák \\
\hline France & Bonnelles & 48.618 & 2.028 & 11 July 2007 & L. Dvořák \\
\hline France & Vincennes & 48.833 & 2.421 & 6 October 2012 & A. Perrard \\
\hline France & Vincennes & 48.833 & 2.421 & 6 October 2012 & A. Perrard \\
\hline
\end{tabular}




\begin{tabular}{|c|c|c|c|c|c|}
\hline Country & Locale & Latitude & Longitude & Collection date & Submitter \\
\hline Germany & Barterode & 51.548 & 9.743 & 11 July 2007 & L. Dvořák \\
\hline Greece & Sultanitsa & 41.317 & 23.201 & 11 July 2007 & L. Dvořák \\
\hline Hungary & Felsotarkany & 47.899 & 20.385 & 20 June 2010 & G. Broad \\
\hline Hungary & Felsotarkany & 47.899 & 20.385 & 20 June 2010 & G. Broad \\
\hline Hungary & Felsotarkany & 47.899 & 20.385 & 20 June 2010 & G. Broad \\
\hline Ireland & Creglucas & 53.225 & -8.865 & 10 July 2006 & L. Dvořák \\
\hline Ireland & County Kildare & 53.340 & -6.538 & 1 September 2012 & R. O'Toole \\
\hline Italy & Pordenone & 46.031 & 12.494 & 7 September 2007 & L. Dvořák \\
\hline Mongolia & Central Aimak & 47.833 & 107.400 & 13 July 2002 & L. Dvořák \\
\hline New Zealand & Otago & -45.890 & 170.500 & 1 March 2013 & T. Harris \\
\hline New Zealand & Otago & -45.890 & 170.500 & 1 March 2013 & T. Harris \\
\hline New Zealand & Otago & -45.890 & 170.500 & 1 March 2013 & T. Harris \\
\hline New Zealand & Otago & -45.890 & 170.500 & 10 March 2013 & T. Harris \\
\hline New Zealand & South Canterbury & -44.632 & 171.141 & 14 February 2013 & T. Harris \\
\hline New Zealand & Canterbury & -42.945 & 171.566 & 28 February 2013 & B. Brown \\
\hline New Zealand & Nelson & -41.808 & 172.851 & 1 April 2012 & P.J. Lester \\
\hline New Zealand & Nelson & -41.803 & 172.846 & 20 February 2011 & P.J. Lester \\
\hline New Zealand & Nelson & -41.803 & 172.846 & 20 February 2011 & P.J. Lester \\
\hline New Zealand & Wellington & -41.286 & 174.776 & 1 May 2012 & J. Barnard \\
\hline New Zealand & Wellington & -41.286 & 174.776 & 1 May 2012 & J. Barnard \\
\hline New Zealand & Wellington & -41.278 & 174.909 & 1 April 2013 & E. Brenton-Rule \\
\hline New Zealand & Wellington & -41.194 & 174.923 & 18 April 2012 & P.J. Lester \\
\hline New Zealand & Wellington & -41.051 & 175.171 & 1 February 2012 & R. Barbieri \\
\hline New Zealand & Wellington & -41.051 & 175.171 & 1 February 2012 & R. Barbieri \\
\hline New Zealand & Wellington & -41.051 & 175.171 & 1 February 2012 & R. Barbieri \\
\hline New Zealand & Wellington & -41.051 & 175.171 & 1 February 2012 & R. Barbieri \\
\hline New Zealand & Castlepoint & -40.900 & 176.217 & 17 February 2013 & P.J. Lester \\
\hline New Zealand & Taupo & -38.683 & 176.083 & 23 February 2013 & E. Brenton-Rule \\
\hline New Zealand & Northland & -35.850 & 174.567 & 20 April 2012 & F.R. Schnitzler \\
\hline New Zealand & Northland & -35.850 & 174.567 & 20 April 2012 & F.R. Schnitzler \\
\hline New Zealand & Northland & -35.725 & 174.324 & 2 May 2012 & B. Thompson \\
\hline $\begin{array}{l}\text { New Zealand } \\
\text { Northern }\end{array}$ & Northland & -35.725 & 174.324 & 2 May 2012 & B. Thompson \\
\hline Ireland & County Down & 54.349 & -6.270 & 1 September 2012 & S. Curran \\
\hline Poland & Góra Pychowicka & 50.031 & 19.883 & 16 August 2006 & $\begin{array}{l}\text { L. Dvořák } \\
\text { A.V. Antropov \& }\end{array}$ \\
\hline Russia & Moscow & 55.215 & 37.913 & 24 August 2012 & $\begin{array}{l}\text { N.A.Khrustalyova } \\
\text { A.V. Antropov \& }\end{array}$ \\
\hline Russia & Moscow & 55.216 & 37.911 & 17 August 2012 & $\begin{array}{l}\text { N.A.Khrustalyova } \\
\text { A.V. Antropov \& }\end{array}$ \\
\hline Russia & Moscow & 55.217 & 37.902 & 24 August 2012 & $\begin{array}{l}\text { N.A.Khrustalyova } \\
\text { A.V. Antropov \& }\end{array}$ \\
\hline Russia & Moscow & 55.409 & 37.906 & 24 August 2012 & N.A.Khrustalyova \\
\hline Slovakia & Dlhé Rovné & 48.636 & 17.530 & 4 August 2004 & L. Dvořák \\
\hline Slovakia & Starý Smokovec & 49.134 & 20.212 & 26 September 2006 & L. Dvořák \\
\hline Spain & Los Cortijos & 40.167 & 1.483 & 16 August 2007 & L. Dvořák \\
\hline Spain & Los Cortijos & 40.167 & 1.483 & 16 August 2007 & L. Dvořák \\
\hline Spain & Teruel & 40.240 & -1.410 & 6 October 2012 & L. Castro \\
\hline Spain & Teruel & 40.408 & 1.444 & 1 October 2012 & L. Castro \\
\hline
\end{tabular}




\begin{tabular}{llllll}
\hline Country & Locale & Latitude & Longitude & Collection date & Submitter \\
\hline Spain & Palencia & 42.996 & -4.531 & 10 August 2012 & L. Castro \\
Spain & Burgos & 43.102 & -3.343 & 23 September 2012 & L. Castro \\
Sweden & Lappland, Abisko & 68.355 & 18.817 & 15 August 2006 & L. Dvoŕák \\
UK & Berkshire & 51.517 & -1.517 & 11 August 2006 & E.G. Chambers \\
UK & Harpendan & 51.816 & -0.361 & 1 September 2010 & M. Archer \\
UK & Harpendan & 51.816 & -0.361 & 1 September 2010 & M. Archer \\
UK & Bucks & 52.229 & -0.926 & 17 August 2011 & G. Broad \\
UK & Bucks & 52.229 & -0.926 & 17 August 2011 & G. Broad \\
UK & Cambridgeshire & 52.325 & -0.073 & 22 June 2013 & H. Berman \\
UK & Lancashire & 53.749 & -2.488 & 1 September 2012 & M. Archer \\
UK & Herts & 53.850 & -1.725 & 7 January 2012 & G. Broad \\
UK & York & 53.962 & -1.082 & 8 October 2012 & M. Archer \\
UK & Hunts & 55.020 & -1.460 & 3 June 2005 & G. Broad \\
UK & Hunts & 55.020 & -1.460 & 3 June 2005 & G. Broad \\
UK & Hunts & 55.020 & -1.460 & 3 June 2005 & G. Broad \\
UK & Lambourn Downs & 51.489 & 1.425 & 10 August 2006 & E.G. Chambers \\
UK & Reading & 51.524 & 1.093 & 10 August 2006 & E.G. Chambers \\
\multicolumn{1}{l}{$\begin{array}{l}\text { Vespula germanica } \\
\text { New Zealand }\end{array}$} & Auckland & & & & \\
& & -36.972 & 174.840 & 25 May 2012 & F.R. Schnitzler \\
\hline
\end{tabular}

48 
49 Table S2 The maximum likelihood fits for the five best-fitting models of the 24

50 different nucleotide substitution models calculated in MEGA 5.1 for the separate $c y t b$

51 and COI datasets and concatenated dataset ( 852 bases). Model abbreviations:

52 HKY=Hasegawa-Kishino-Yano; TN93=Tamura-Nei; T92=Tamura 3-parameter. The

53 best-fitting substitution model was selected based on Bayesian Information Criterion

54 scores (BIC). For each model the corrected Akaike Information Criterion value

55 (AICc), Maximum Likelihood value $(\operatorname{lnL})$, and the number of parameters are also

56 presented. Models with the lowest BIC, AICc and $\mathrm{lnL}$ scores describe the substitution

57 pattern the best. Variable model parameters included non-uniformity of evolutionary

58 rates among sites (a discrete Gamma distribution $(+\mathrm{G})$ with 5 rate categories) and the

59 assumption that a certain fraction of sites are evolutionarily invariable $(+\mathrm{I})$. Where

60 applicable the estimates of $+\mathrm{G}$ and $+\mathrm{I}$ are shown. The number of parameters in the

61 model (\#), and the assumed or estimated values of transition/transversion bias (R) are

62 also shown. MEGA also calculated nucleotide frequencies (f) and rates of base

63 substitutions (r) for each nucleotide pair (data not shown)

\begin{tabular}{cllcccccc}
\hline Dataset & Model & $\#$ & BIC & AICc & InL & $+\mathbf{I}$ & $+\mathbf{G}$ & $\mathbf{R}$ \\
\hline Composite & HKY+G & 110 & 4867 & 3907 & -1843 & - & 0.16 & 2.09 \\
& HKY+G+I & 111 & 4874 & 3901 & -1841 & 0.57 & 0.63 & 2.21 \\
& TN93+G & 111 & 4878 & 3909 & -1843 & - & 0.16 & 2.09 \\
& T93+I & 108 & 4881 & 3912 & -1844 & 0.75 & - & 2.11 \\
& TN92+G & 112 & 4883 & 3940 & -1861 & - & 0.15 & 2.22 \\
\hline COI & T92+I & 110 & 2856 & 1972 & -875 & 0.82 & - & 3.69 \\
& T92+G & 110 & 2857 & 1973 & -876 & - & 0.05 & 3.19 \\
& HKY+G & 112 & 2862 & 1962 & -868 & - & 0.06 & 2.75 \\
& HKY+I & 112 & 2862 & 1962 & -868 & 0.81 & - & 2.83 \\
& T92+G+I & 111 & 2864 & 1972 & -874 & 0.70 & 0.51 & 3.75 \\
\hline cytb & HKY & 111 & 2896 & 2000 & -888 & - & - & 1.63 \\
& HKY+G & 112 & 2900 & 1997 & -886 & - & 0.58 & 1.77 \\
& T92 & 109 & 2901 & 2022 & -901 & - & - & 1.63 \\
& TN93 & 112 & 2903 & 1999 & -887 & - & - & 1.65 \\
& HKY+I & 112 & 2905 & 2001 & -888 & 0.12 & - & 1.65 \\
\hline
\end{tabular}

64

65 
1

2
66 Table S3 Results of GLM analysis comparing: a) the genetic distance between 67 the New Zealand samples and all other regions; and b) the genetic distance between 68 the Argentina samples and all other regions

69

\begin{tabular}{lllrr}
\hline & Region & difference & t & \multicolumn{1}{c}{ p } \\
\hline a) & New Zealand & & \\
& Argentina & 1.0 times greater & 0.78 & 0.436 \\
& UK and Ireland & 2.0 times greater & 6.72 & $<0.001$ \\
& Western Europe & 5.5 times greater & 17.54 & $<0.001$ \\
& Northern Europe & 7.2 times greater & 19.48 & $<0.001$ \\
& Eastern Europe & 7.1 times greater & 19.92 & $<0.001$ \\
& Asia & 38.5 times greater & 34.33 & $<0.001$ \\
\hline b) Argentinan & & & \\
& New Zealand & 1.4 times greater & 1.30 & 0.195 \\
& UK and Ireland & 3.2 times greater & 4.78 & $<0.001$ \\
& Western Europe & 8.9 times greater & 9.18 & $<0.001$ \\
& Northern Europe & 9.8 times greater & 9.21 & $<0.001$ \\
& Eastern Europe & 11.9 times greater & 10.41 & $<0.001$ \\
& Asia & 60.4 times greater & 16.66 & $<0.001$ \\
\hline
\end{tabular}

Table S4 Matrix of pairwise genetic distances between individuals using the Tamura-Nei model (Tamura and Nei 1993). (Refer to Lester et al Origin of Vespula vulgaris SUP_MAT.xlsx) 
77 Table S5 PCR results from triplicate PCRs including

78 positives and negatives. Positive samples were sequenced and

79 BLASTn searched to confirm they were microsporidia

\begin{tabular}{lcccc}
\hline Region & PCR1 & PCR2 & PCR3 & Total positive \\
\hline Argentina & 0 & 0 & 0 & 0 \\
Argentina & 0 & 0 & 0 & 0 \\
Argentina & 0 & 0 & 0 & 0 \\
Argentina & 0 & 0 & 0 & 0 \\
Argentina & 0 & 0 & 0 & 0 \\
Argentina & 0 & 0 & 0 & 0 \\
Argentina & 0 & 0 & 0 & 0 \\
Argentina & 0 & 0 & 0 & 0 \\
Argentina & 0 & 0 & 0 & 0 \\
Argentina & 0 & 0 & 1 & 1 \\
Argentina & 0 & 1 & 0 & 1 \\
Argentina & 0 & 0 & 1 & 1 \\
Argentina & 0 & 0 & 0 & 0 \\
Argentina & 0 & 1 & 0 & 1 \\
Argentina & 1 & 1 & 0 & 2 \\
Argentina & 1 & 0 & 0 & 1 \\
Argentina & 1 & 0 & 0 & 1 \\
Argentina & 0 & 0 & 0 & 0 \\
Argentina & 0 & 0 & 0 & 0 \\
China & 0 & 0 & 0 & 0 \\
Eastern Europe & 0 & 0 & 0 & 0 \\
Eastern Europe & 0 & 0 & 0 & 0 \\
Eastern Europe & 0 & 0 & 0 & 0 \\
Eastern Europe & 0 & 0 & 0 & 0 \\
Eastern Europe & 0 & 0 & 0 & 0 \\
Eastern Europe & 0 & 0 & 0 & 0 \\
Eastern Europe & 0 & 0 & 0 & 0 \\
Eastern Europe & 0 & 0 & 0 & 0 \\
Eastern Europe & 0 & 1 & 1 & 2 \\
Eastern Europe & 0 & 1 & 0 & 1 \\
Eastern Europe & 0 & 1 & 0 & 1 \\
Eastern Europe & 0 & 0 & 0 & 0 \\
Eastern Europe & 1 & 0 & 0 & 1 \\
eastern_europe & 1 & 0 & 0 & 1 \\
Eastern Europe & 0 & 0 & 1 & 1 \\
New Zealand & 0 & 0 & 0 & 0 \\
New Zealand & 0 & 0 & 0 & 0 \\
New Zealand & 0 & 1 & 0 & 1 \\
New Zealand & 1 & 1 & 0 & 2 \\
& & & & 0 \\
\hline
\end{tabular}




\begin{tabular}{|c|c|c|c|c|}
\hline Region & PCR1 & PCR2 & PCR3 & Total positive \\
\hline New Zealand & 0 & 1 & 1 & 2 \\
\hline New Zealand & 1 & 0 & 0 & 1 \\
\hline New Zealand & 0 & 0 & 0 & 0 \\
\hline New Zealand & 0 & 0 & 0 & 0 \\
\hline New Zealand & 0 & 1 & 1 & 2 \\
\hline New Zealand & 0 & 1 & 1 & 2 \\
\hline New Zealand & 0 & 0 & 0 & 0 \\
\hline New Zealand & 1 & 1 & 1 & 3 \\
\hline New Zealand & 0 & 1 & 1 & 2 \\
\hline New Zealand & 0 & 1 & 0 & 1 \\
\hline New Zealand & 0 & 0 & 0 & 0 \\
\hline New Zealand & 0 & 0 & 1 & 1 \\
\hline New Zealand & 0 & 0 & 1 & 1 \\
\hline New Zealand & 0 & 1 & 0 & 1 \\
\hline New Zealand & 0 & 0 & 0 & 0 \\
\hline New Zealand & 0 & 0 & 0 & 0 \\
\hline New Zealand & 0 & 0 & 0 & 0 \\
\hline New Zealand & 0 & 1 & 1 & 2 \\
\hline New Zealand & 0 & 1 & 1 & 2 \\
\hline New Zealand & 0 & 0 & 0 & 0 \\
\hline New Zealand & 0 & 0 & 0 & 0 \\
\hline New Zealand & 0 & 1 & 0 & 1 \\
\hline New Zealand & 1 & 0 & 0 & 1 \\
\hline New Zealand & 0 & 0 & 0 & 0 \\
\hline New Zealand & 0 & 0 & 0 & 0 \\
\hline New Zealand & 0 & 1 & 0 & 1 \\
\hline New Zealand & 0 & 1 & 0 & 1 \\
\hline New Zealand & 0 & 0 & 0 & 0 \\
\hline New Zealand & 0 & 0 & 0 & 0 \\
\hline New Zealand & 0 & 0 & 0 & 0 \\
\hline New Zealand & 0 & 1 & 0 & 1 \\
\hline New Zealand & 0 & 1 & 0 & 1 \\
\hline New Zealand & 0 & 0 & 0 & 0 \\
\hline New Zealand & 0 & 0 & 0 & 0 \\
\hline Northern Europe & 0 & 0 & 0 & 0 \\
\hline Northern Europe & 0 & 0 & 0 & 0 \\
\hline Northern Europe & 0 & 0 & 0 & 0 \\
\hline Northern Europe & 0 & 0 & 0 & 0 \\
\hline Northern Europe & 0 & 0 & 0 & 0 \\
\hline Northern Europe & 0 & 0 & 0 & 0 \\
\hline Northern Europe & 1 & 0 & 0 & 1 \\
\hline UK \& Ireland & 0 & 0 & 0 & 0 \\
\hline UK \& Ireland & 0 & 0 & 0 & 0 \\
\hline
\end{tabular}




\begin{tabular}{|c|c|c|c|c|}
\hline Region & PCR1 & PCR2 & PCR3 & Total positive \\
\hline UK \& Ireland & 0 & 0 & 0 & 0 \\
\hline UK \& Ireland & 0 & 1 & 0 & 1 \\
\hline UK \& Ireland & 0 & 1 & 1 & 2 \\
\hline UK \& Ireland & 0 & 1 & 1 & 2 \\
\hline UK \& Ireland & 0 & 1 & 0 & 1 \\
\hline UK \& Ireland & 0 & 0 & 0 & 0 \\
\hline UK \& Ireland & 0 & 0 & 1 & 1 \\
\hline UK \& Ireland & 0 & 0 & 0 & 0 \\
\hline UK \& Ireland & 0 & 0 & 0 & 0 \\
\hline UK \& Ireland & 0 & 0 & 0 & 0 \\
\hline UK \& Ireland & 0 & 0 & 0 & 0 \\
\hline UK \& Ireland & 0 & 0 & 0 & 0 \\
\hline UK \& Ireland & 0 & 0 & 0 & 0 \\
\hline UK \& Ireland & 1 & 0 & 0 & 1 \\
\hline UK \& Ireland & 0 & 0 & 0 & 0 \\
\hline UK \& Ireland & 0 & 0 & 0 & 0 \\
\hline UK \& Ireland & 0 & 0 & 1 & 1 \\
\hline UK \& Ireland & 0 & 0 & 0 & 0 \\
\hline UK \& Ireland & 0 & 0 & 0 & 0 \\
\hline UK \& Ireland & 1 & 0 & 1 & 2 \\
\hline UK \& Ireland & 1 & 0 & 0 & 1 \\
\hline UK \& Ireland & 1 & 0 & 0 & 1 \\
\hline UK \& Ireland & 0 & 0 & 0 & 0 \\
\hline Western Europe & 0 & 0 & 0 & 0 \\
\hline Western Europe & 0 & 0 & 1 & 1 \\
\hline Western Europe & 1 & 0 & 0 & 1 \\
\hline Western Europe & 0 & 1 & 0 & 1 \\
\hline Western Europe & 0 & 1 & 0 & 1 \\
\hline Western Europe & 0 & 0 & 0 & 0 \\
\hline Western Europe & 0 & 1 & 0 & 1 \\
\hline Western Europe & 0 & 0 & 1 & 1 \\
\hline Western Europe & 0 & 0 & 0 & 0 \\
\hline Western Europe & 0 & 0 & 0 & 0 \\
\hline Western Europe & 0 & 0 & 0 & 0 \\
\hline Western Europe & 0 & 0 & 0 & 0 \\
\hline Western Europe & 0 & 0 & 0 & 0 \\
\hline Western Europe & 0 & 0 & 0 & 0 \\
\hline Western Europe & 0 & 0 & 0 & 0 \\
\hline Western Europe & 0 & 0 & 0 & 0 \\
\hline Western Europe & 0 & 0 & 0 & 0 \\
\hline Western Europe & 0 & 0 & 0 & 0 \\
\hline Western Europe & 0 & 0 & 0 & 0 \\
\hline Western Europe & 0 & 0 & 0 & 0 \\
\hline
\end{tabular}


1

2

3

4

5

6

7

8

9

10

11

12

13

14

15

16

17

18

19

20

21

22

23

24

25

26

27

28

29

30

31

32

33

34

35

36

37

38

39

40

41

42

43

44

45

46

47

48

49

50

51

52

53

54

55

56

57

58

59

60

\begin{tabular}{lcccc}
\hline Region & PCR1 & PCR2 & PCR3 & Total positive \\
\hline Western Europe & 0 & 0 & 0 & 0 \\
Western Europe & 0 & 1 & 1 & 2 \\
Western Europe & 0 & 0 & 0 & 0 \\
Western Europe & 0 & 0 & 0 & 0 \\
Western Europe & 0 & 0 & 0 & 0 \\
Western Europe & 0 & 0 & 0 & 0 \\
Western Europe & 0 & 0 & 0 & 0 \\
\hline
\end{tabular}

80

Diversity and Distributions 